\title{
Comic "Gora" in the textbook serial BIPA Dahsyat: media increase vocabulary mastery in learning Indonesian for foreign Speakers
}

\author{
Randi Ramliyana*) \\ Universitas Indraprasta PGRI \\ *) Correspondences author: Jalan Raya Tengah No. 80, RT.9/RW.8, Gedong, Pasar Rebo, RT.1/RW.3, Gedong, \\ Kota Jakarta Timur, Daerah Khusus Ibukota Jakarta 13760, Indonesia; \\ e-mail: randi.ramliyana@gmail.com
}

\begin{abstract}
Talking is one and the four skills in language that is productive and active Because of them that, a lot of foreign speakers have difficulty when first learning to speak in Indonesian one problem often encountered is the limited vocabulary that is owned by a foreign speaker Many instructional media offered to increase the amount of vocabulary for speakers Asung, one of which is the media images media images can increase $400 \%$ ability of foreign speakers in remembering vocabulary in the classroom, therefore, the authors developed a media joyful learning in the form of a comic comics is a combination of pictures and words capable of arouse and excite the foreign speakers to continue to learn to speak in a way that is fun this paper will describe a form of learning berbucara who could inspire and stimulate foreign speakers as well as fun in the classroom through the comic making it easier for foreign speakers achieve the goal of learning to speak.
\end{abstract}

Keywords: comic images, vocabulary, talk, inspire, and excite.

Article History: Received: 01/03/2017; Revised: 25/03/2017; Accepted: 09/04/2017; Published: 05/05/2017

How to Cite (MLA 7 ${ }^{\text {th }}$ ): Ramliyana, Randi. "Comic "Gora" in the textbook serial BIPA Dahsyat: media increase vocabulary mastery in learning Indonesian for foreign Speakers." Hortatori: Jurnal Pendidikan Bahasa dan Sastra Indonesia 1.1 (2017): 79-84. Print/Online. Copyrights Holder: Ramliyana, Randi. First Publication: Hortatori Jurnal Pendidikan Bahasa dan Sastra Indonesia (2017).

This work is licensed under a Creative Commons Attribution-ShareAlike 4.0 International License.

\section{Pendahuluan}

Bahasa Indonesia bagi Penutur Asing (BIPA) kini menjadi salah satu kebutuhan yang harus diambil para warga negara asing yang ingin bekerja di Indonesia. Kebutuhan tersebut disambut baik oleh para pegiat BIPA di seluruh Indonesia. Banyak lembaga-lembaga membuka program BIPA untuk memenuhi kebutuhan tersebut. Seiring berjalannya program BIPA, banyak permasalahan yang timbul selama proses pembelajaran berlangsung. Baik dari permasalahan seputar budaya dan bahasa yang diajarkan di kelas.

Permasalahan pengajaran bahasa merupakan permasalahan umum yang sering dihadapi pengajar BIPA. Seperti yang diketahui, kemampuan berbahasa terdiri atas empat kemampuan yang berkesinambungan satu dengan yang lainnya. Empat kemampuan tersebut ialah kemampuan menyimak, berbicara, membaca, dan menulis. Dalam pembelajaran bahasa, siswa dituntut untuk menugasi semua kemampuan berbahasa. Terutama bagi siswa asing yang dituntut untuk menguasai bahasa Indonesia minimal selama 60 jam. Belajar bahasa tidak seperti pelajaran lainnya yang menuntut siswa untuk hafal dan paham saja, tetapi menuntut siswa untuk terampil dan mampu berbahasa dengan baik. Di sinilah, pengajar BIPA bertugas menyediakan dan menciptakan suasana menyenangkan selama proses pembelajaran.

Banyak cara menciptakan suasana yang menyenangkan ke dalam proses pembelajaran. Salah satunya dengan menggunakan media pembelajaran yang menarik, yaitu komik. Komik disukai karena sangat menyenangkan untuk dibaca dan juga memberikan beragam informasi di dalamnya. Oleh karena itu, 
komik dapat menjadi media pembelajaran yang efektif, karena siswa BIPA senang membacanya dan mendapatkan materi pembelajaran (edukatif) di dalamnya.

Komik sebagai media pembelajaran sudah lama diterapkan dan memberikan dampak yang positif selama proses pembelajaran (Ramliyana, 2010). Media komik selain menyenangkan, juga selalu dikaitkan dapat meningkatkan minat membaca, serta mengembangkan perbendaharaan kosakata dalam berbahasa. Komik digunakan sebagai langkah awal untuk membangkitkan minat membaca siswa, terutama yang tidak suka membaca. Selain karena komik menghibur, menyenangkan dan edukatif, komik juga merupakan jembatan untuk membaca buku yang lebih serius.

Masalah yang sering terjadi saat ini pada siswa BIPA adalah kurangnya perbendaharaan kosakata yang mereka miliki sehingga mengakibatkan kesulitan dalam berbicara dan menulis. Kurangnya perbendaharaan kosakata pada siswa BIPA dikarenakan mereka sulit mengingat kosakata bahasa Indonesia yang baru mereka pelajari sebagai bahasa kedua.

Kurangnya perbendaharaan kosakata siswa BIPA menghambat kemampuan berbahasa lainnya seperti menulis dan berbicara. Terutama dalam kemampuan berbicara, siswa BIPA diharapkan dapat berbicara dan berkomunikasi menggunakan bahasa Indonesia dalam percakapan sehari-hari. Di sinilah, media komik menjadi jembatan bagi siswa BIPA dalam meningkatkan jumlah perbendaharaan kosakata bahasa Indonesia mereka agar memperlancar kemampuan berbicara mereka dalam percapakan sehari-hari. Penguasaan kosakata adalah pemahaman seseorang untuk menggunakan himpunan kata dan kemampuan kata yang dimilikinya dan dapat menggunakannya dalam suatu bahasa. Penguasaan kosakata sangatlah penting untuk memperlancar kegiatan pembelajaran BIPA. Tanpa mengetahui kosakata, siswa akan mengalami hambatan dalam pembelajaran bahasa Indonesia. Dalam pembelajaran bahasa Indonesia, materi tentang kosakata adalah materi yang pertama kali diajarkan sebelum materi lainnya, karena kemampuan menguasai materi ini merupakan dasar untuk mempelajari materi bahasa Indonesia selanjutnya. Indikasi bahwa seseorang menguasai kosakata dapat dilihat dari kemampuan mengucapkan dan mengetahui arti kata yang diucapkan sehingga orang lain dapat memahaminya dengan mudah. Banyaknya jumlah kosakata yang dimiliki seseorang akan mempengaruhi terhadap kemampuan kosakatanya.

Peneliti melihat pelaksanaan pembelajaran BIPA masih konvensional di BIPA Universitas Multimedia Nusantara (UMN). Pengajar mengalami kesulitan dalam membelajarkan kosakata bahasa Indonesia kepada siswa BIPA. Pengajar hanya membelajarkan kosakata Bahasa Indonesia dengan cara menuliskan kosakata di papan tulis kemudian mengajak siswa membaca bersama-sama. Membaca kosakatanya pun hanya beberapa kali sehingga siswa sering lupa dengan kosakata yang baru saja dipelajarinya. Mereka masih sangat kesulitan dalam mengingat-ingat kosakata. Hal ini terbukti ketika pengajar mengadakan tanya jawab tentang kosakata, siswa lebih banyak diam karena lupa. Berdasarkan kondisi tersebut maka diperlukan perbaikan pembelajaran melalui penelitian tindakan kelas. Peneliti mencoba untuk mencari inovasi dalam menyampaikan materi kosakata bahasa Indonesia, yaitu dengan menggunakan media komik.

Oleh sebab itu, penelitian ini akan berfokus pada penggunaan Komik "Gora" pada Buku Ajar Serial BIPA Dahsyat: Media Peningkatan Penguasaan Kosakata dalam Belajar Bahasa Indonesia bagi Penutur Asing. Peneliti berharap penelitian ini akan berguna bagi dunia pendidikan, terutama pada pembelajaran BIPA di Indonesia dan memberikan solusi baru dengan menggunakan komik sebagai media pembelajaran yang menyenangkan dan tepat bagi semua siswa BIPA.

\section{Metode}

Penelitian deskriptif kualitatif ini diawali dengan pengumpulan data, kemudian analisis data dan sajian hasil analisis data. Pengumpulan data dilakukan dengan teknik penelusuran pustaka dan wawancara mendalam dengan beberapa narasumber. penelitian ini akan berfokus pada penggunaan Komik "Gora" pada Buku Ajar Serial BIPA Dahsyat: Media Peningkatan Penguasaan Kosakata dalam Belajar Bahasa Indonesia bagi Penutur Asing. Peneliti berharap penelitian ini akan berguna bagi dunia pendidikan, terutama pada pembelajaran BIPA di Indonesia dan memberikan solusi baru dengan menggunakan komik sebagai media pembelajaran yang menyenangkan dan tepat bagi semua siswa BIPA.

Data hasil analisis tersebut kemudian disajikan dengan memberikan penjelasan secara deskriptif berdasarkan tujuan dalam penelitian ini. Deskripsi tersebut kemudian disajikan secara informal dengan 
menggunakan uraian kata-kata biasa dari penulis dan secara formal menggunaan tanda atau lambanglambang, termasuk tabel, bagan, gambar, dll (Sudaryanto, 1993).

\section{Hasil dan Diskusi}

\section{Strategi Pembelajaran Kosakata}

Pembelajaran kosakata dapat dikembangkan secara umum berdasarkan kelas kata yang ada. Dari satu kata dapat dikembangkan dengan luas dan mendapatkan kelas kata yang lainnya dengan menghubungkan kata-kata tersebut. Misalnya, kata orang (person) yang masuk dalam kelas kata benda (noun) dapat dikembangkan dengan pertanyaan, “Apa saja yang Anda lihat dari orang ini?" jawabnya adalah kepala (head), tangan (hands), badan (body), kaki (foots) dll. Berdasarkan jawaban yang ada, muncul kelas kata benda (noun). Bila terdapat pertanyaan, "Bagaimanakah orang itu?" maka jawaban yang muncul adalah tinggi (tall), kurus (thin), tampan (handsome), menarik (interesting), dll. yang memunculkan kelas kata baru, yaitu kelas kata sifat (adjective). Lain halnya bila menggunakan kalimat pertanyaan "Apa yang dilakukan orang itu?" maka jawaban yang ada adalah berjalan (walking), berlari (run), menari (dance), melompat (jump) dll. Jawaban tersebut memunculkan kelas kata kerja (verb). Lalu pertanyaan dikembangkan menjadi, "Bagaimana orang itu berlari?" maka jawaban yang muncul adalah berlari dengan cepat (run fastly), berjalan dengan pelan (walk slowly), dll. yang lebih menekankan pada cara. Bila ingin lebih mengembangkan penguasaan kosakata tersebut dengan mencari kelas kata depan (preposition) maka dapat dilakukan dengan pertanyaan "Di manakah pada umumnya orang berlari?" maka jawabanya adalah di taman kota (at the city park), di gelanggang olahraga (in the sport hall), dll.

Menurut Singleton (2008), pembelajar bahasa pada umumnya penerima yang pasif, walaupun dalam beberapa prosedur pembelajaran, pembelajar tersebut dapat ikut berpartisipasi. Pengajar memberikan makna dan bentuk dari suatu leksikal. Arti leksikal tersebut dapat disajikan, baik secara lisan maupun tertulis. Cara yang pada umumnya digunakan dalam mengajarkan kosakata adalah sebagai berikut.

1. Menghubungkan antara bahasa kedua (bahasa Indonesia) dengan bahasa pertama (bahasa asli siswa BIPA).

Strategi pembelajaran bahasa ini biasanya digunakan pada saat memeriksa pemahaman siswa tetapi dapat pula digunakan saat mencari persamaan dan perbedaan antara bahasa 2 dengan bahasa 1, terutama saat hal yang sedang dipelajari ini dirasa akan menimbulkan banyak kesalahan.

2. Mendefinisikan arti.

Definisi dapat berbentuk sebagai: sinonim, antonim, definisi analitik ( $X$ is a $Y$ which), definisi taksonomi (Autumn is a season), memberikan contoh atau lawan kata, memberikan superordinat dari suatu bentuk kata (rose is a flower), menjelaskan fungsi, definisi gramatikal (worse, comparison of bad), definisi melalui penghubungan (danger, lives have not been protected), definisi dengan pengklasifikasian (family, a group of people), dan definisi penuh.

3. Presentasi dengan menghubungkan kata-kata

Pengajar menciptakan suatu situasi (skenario) yang mendekati dengan konteks apa yang ingin diajarkan. Konteks dapat diberikan dalam satu kalimat saja, tetapi pengajar juga dapat memberikan beberapa kalimat di mana kata yang dimaksud juga muncul. Siswa lalu menebak arti dari kalimatkalimat tersebut.

4. Menghubungkan secara langsung antara arti kata dengan benda atau peristiwa.

Strategi ini sering digunakan untuk siswa yang pemula atau masih kecil. Prosedurnya meliputi demonstrasi dan bantuan gambar (secara visual) yang juga dapat digunakan sebagai isyarat untuk dapat mengingat suatu kata.

5. Keterlibatan aktif dari siswa dalam suatu presentasi

Di sini pengajar memberikan dorongan kepada siswa untuk menemukan arti kata dari bagianbagiannya atau dengan memberikan bantuan, seperti pengajar menunjukkan sebuah gambar dan mengundang siswa untuk memberikan penjelasan atau pengajar dapat memberikan suatu kata dan membiarkan siswa mencari definisi atau sinonimnya.

Dalam rangka untuk menghasilkan hubungan antara arti kata dengan bentuknya, siswa perlu untuk distimulasi atau dirangsang untuk memahami pelafalan dari suatu kata tersebut. Berikut ini adalah beberapa cara yang dapat dilakukan.

1. Latihan Oral (oral drill) 
Pengajar melafalkan kata beberapa kali dan siswa mendengarkan, kemudian siswa mengulanginya dengan suara lantang (berkelompok atau perseorangan), selanjutnya siswa melafalkan kata-kata tersebut kepada diri mereka sendiri (dengan suara yang pelan).

2. Tulisan fonetik dan grafik presentasi

Tulisan fonetik dan grafik presentasi di sini dimaksudkan agar siswa lebih mudah mempelajari pelafalan bunyi dari suatu kata seperti bunyi yang panjang dituliskan dengan tanda di atas atau di sekitarnya.

3. Menjelaskan dengan bentuk grafik

Cara ini dapat digunakan dengan menulis di papan tulis, menggarisbawahi kata yang dipelajari atau menebalkannya untuk memudahkan melihat.

4. Mendorong siswa untuk mencoba dan melafalkan.

\section{Aspek yang memengaruhi kemampuan berbicara}

Dalam rangka pembinaan keterampilan berbicara, hal yang perlu mendapat perhatian pengajar dalam keefektifan berbicara menurut Arsyad ada dua aspek: aspek kebahasaan mencakup (a) lafal, (b) intonasi, tekanan, dan ritme, dan (c) penggunaan kata dan kalimat, dan aspek non-kebahasaan yang mencakup : (a) kenyaringan suara, (b) kelancaran, (c) sikap berbicara, (d) gerak dan mimik, (e) penalaran, (f) santun berbicara.

Jalongo (1992) menyatakan pendapatnya bahwa dalam praktek berbahsa baik dalam bentuk reseptif maupun produktif/ekspresif komponen kebahasaan akan selalu muncul. Komponen kebahasaan tersebut adalah : (a) fonologi, (b) sintaksis, (c) semantik, ddan (d) pragmatik.

Berkaitan dengan kemampuan fonologis anak di tuntut untuk menguasai sistem bunyi. Tingkah laku yang tampak pada anak adalah pemahaman serta pemproduksian bunyi-bunyi bahasa, seperti tekanan, nada, dan kesenyapan.Komponen sintaksis menurut penguasaan gramatikal. Tingkah laku sintatik pada diri siswa adalah pengenalan struktur ucapan, serta pemproduksian kecepatan struktur ujaran.

Komponen semantik berkaitan dengan penguasaan sistem makna. Tingkah laku semantik pada diri siswa adalah pemahaman akan makna, sedangkan produksinyaa berupa ujaran yang bermakna. Sedangkan komponen pragmatik menurut siswa akan sistem interaksi sosial makna. Tingkah laku pragmatik yang tampak paada diri siswa adalah pemahaman terhadap implikasi sosial dari suatu ujaran. Produksinya berupaa ujaran-ujaran yang sesuai dengan situasi sosial, situasi sosial itu berhubungan dengan: (a) siapa yang berbicara, (b) dengan siapa berbicara, (c) apa yang dibicarakan, (d) bagaimana membicarakan, (e) kapan dan di mana dibicarakan, (f) menggunakan media apa dalam membicarakan (Hymes).

Dari aspek kebahasaan dan non-kebahasaan yang telah disebutkan di atas, guru dapat mengefektifkan penggunaaan serta mengontrol kesalahan yang terjadi pada siswa.sehingga siswa dalam melaksanakan tindakan berbicara dapat menghindari kesalahan-kesalahan yang mungkin terjadi. Ellis (1989) menyatakan pendapatnya bahwa respon guru pada bahasa yang digunakan anak akan memberikan nilai bahwa guru menempatkan belajar dan bahasa bersama-sama. Cara yang digunakan guru dapat membangun kepercayaan diri siswa untuk berbicara antara lain guru harus dapat memilih waktu yang tepat untuk mendiskusikan penggunaan bahasa yuang tepat atau gaya penyajian yang benar.

Kegiatan Yang Memberikan Kesempatan Kepada Anak Untuk Latihan Menggunakan bahasa Lisan. Tompkins dan Hoskisson (1991) membagi kegiatan berbahsa lisan sebagai berikut.

1. Kegiatan berbicara informal, meliputi percakaapan, menunjuk dan menceritakan, serta diskusi.

2. Kegiatan berbicara interpretatif meliputi, pengisahan cerita dan pembacaan drama.

3. Kegiatan yang lebih formal meliputi laporan lisan, wawancara dan debat.

4. Kegiatan dramatis, meliputi bermain drama, bermain peran, bermain boneka tangan, penulisan naskah dan produksi teater, dan sebagainya.

Menurut Ellis, Standal, Pennau, dan Rummel (1989) kegiatan yang dapat memberikan kesempatan kepada ssiwa untuk berlatih menggunakan bahasa lisan antara lain diskusi, pelaporan, pengisahan cerita, paduan suara, drama, improvisasi, dan kegiatan komunikasi lisan yang lainnya.

\section{Pembelajaran Berbicara Menggunakan Komik}

Siswa BIPA adalah siswa penutur asing yang sedang belajar bahasa Indonesia sebagai bahasa kedua mereka. Pembelajaran bahasa sebagai bahasa kedua harus memerhatikan banyak hal, salah satunya 
kendala penyampaian informasi karena perbedaan bahasa yang terjadi antara siswa dan pengajar BIPA. Banyak pengajar BIPA yang mengalami kendala bahasa pengantar yang digunakan, akibatnya hanya sedikit kosakata yang diingat daripada yang diajarkan di dalam kelas BIPA. Salah satu solusi terbaik dari masalah tersebut adalah menggunakan bahasa visual. Media visual dapat meningkatkan keterampilan siswa mengingat pelajaran sebanyak $400 \%$ dari sebelumnya. Selain itu, otak manusia juga lebih mudah mengingat dan memproses gambar daripada tulisan. Oleh karena itu, peneliti memilih komik sebagai media yang digunakan untuk mengatasi kendala bahasa yang terjadi di antara siswa dan pengajar BIPA.

Komik merupakan hal baru dalam dunia BIPA. Komik sudah lama digunakan sebagai salah satu media pembelajaran yang efektif. Banyak penelitian mengenai komik sebagai salah satu media efektif dalam meningkatkan kosakata pada siswa. Oleh karena itu, peneliti membuat komik berbicara "Gora" pada serial Buku BIPA Dahsyat...! yang menceritakan tentang keluarga Kanigoro yang kedatangan tamu dari Korea Selatan.

Komik "Gora" pada serial Buku BIPA Dahsyat...! sudah diterapkan di BIPA UMN. Penggunaan komik "Gora" pada serial Buku BIPA Dahsyat...! dapat dilakukan seperti membaca dialog-dialog yang terjadi di dalam komik dengan tema-tema yang disesuaikan dengan kebutuhan para siswa BIPA. Fokus dari pembelajaran komik "Gora" pada serial Buku "Gora" pada serial Buku BIPA Dahsyat...! ini adalah keterampilan berbicara siswa. Pengajaran menggunakan komik "Gora" pada serial Buku BIPA Dahsyat...! ini dapat dilakukan bersama dengan membagi peranan tokoh di dalamnya. Dengan membaca dan berbicara setiap teks dialog yang ada. Berikan instruksi kepada mereka untuk menandai kosakata baru yang mereka temui juga kosakata yang mereka tidak ketahui artinya. Setelah membaca satu kali, mereka akan mengajukan pertanyaan mengenai kosakata yang dianggap sulit. Setelah dijelaskan, siswa dapat membaca lagi satu sampai dua kali lagi. Langkah selanjutnya, siswa diusahakan untuk membuat struktur dialog yang serupa dengan kosakata yang sudah mereka miliki atau baru dipelajari.

\section{Simpulan}

Berdasarkan dari pembahasan di atas dapat disimpulkan bahwa kendala bahasa pengantar yang digunakan untuk siswa BIPA tingkat prapemula dan pemula dapat diatasi dengan media visual. Media visual yang diterapkan di kelas dapat meningkatkan $400 \%$ informasi yang dapat diserap di dalam otak siswa. Oleh karena itu, komik "Gora" pada serial Buku BIPA Dahsyat...! dibuat untuk menjadi jawaban atas kendala bahasa pengantar di dalam kelas. Setelah diterapkan selama satu semester di BIPA UMN hasil yang didapat siswa sangat antusias menggunakan media ini dan latihan yang interaktif mampu membuat siswa belajar dan mengingat kosakata lebih banyak dibandingkan siswa BIPA UMN semester lalu yang belum menggunakan media komik "Gora" pada serial Buku BIPA Dahsyat.

\section{Ucapan Terima Kasih}

Terima kasih kepada semua pihak yang membantu penulis dalam menyelesaikan artikel hasil riset ini sehingga bisa diterbitkan di Jurnal Hortatori.

\section{Daftar Rujukan}

Arysad, A. Media pembelajaran. Jakarta: PT Raja Grafindo Persada, 2005. Print.

Eisner, W. Comics and sequential art. Florida: Poorhouse Press, 1986. Print.

Finoza, L. Komposisi bahasa Indonesia. Jakarta: Diksi Insan Mulia, 2009. Print.

Given, B.K. Brain based teaching. Bandung: Kaifa PT Mizan Pustaka, 2007. Print.

Hurlock, E.B. Child development. Jakarta: Erlangga, 2000. Print.

Kadir, A. Misteri otak kiri manusia. Jogjakarta: Diva Press, 2010. Print.

Masdiono, T. 14 Jurus membuat komik. Jakarta: Creativ Media, 2001. Print.

McCloud, S. Understanding comic. Jakarta: Kepustakaan Populer Gramedia, 2001. Print.

. Membuat komik. Jakarta: PT Gramedia Pustaka Utama, 2008. Print.

Muhammad, A. Miliaran keluarbiasaan otak kita. Jogjakarta: Flashbook, 2010. Print.

Muhammad, N. Memahami cara kerja gelombang otak manusia. Jogjakarta: Diva Press, 2011. Print.

Rahayu, M. Bahasa Indonesia di perguruan tinggi. Jakarta: PT Grasindo, 2009. Print. 
84 Comic "Gora" in the textbook serial BIPA Dahsyat: media increase vocabulary mastery in learning Indonesian for foreign Speakers

Sadiman, A. Media pendidikan. Jakarta: PT Raja Grafindo, 2009. Print.

Solso, R.L., Otto H. Maclin, dan M. Kimberly Maclin. Psikologi kognitif. Jakarta: Erlangga, 2007. Print.

Sousa, D.A. Bagaimana otak yang berbakat belajar. Jakarta: PT Indeks, 2012. Print.

. Bagaimana otak belajar. Jakarta: PT Indeks, 2012. Priint.

Stenberg, R.J. Psikologi kognitif. Jogjakarta: Pustaka Pelajar, 2008. Print.

Sudjana, N. dan Rivai Ahmad. Media pengajaran. Bandung: CV Sinar Baru Bandung, 1991. Print. 